\title{
Employer requirements and employability mindsets influencing graduate workers' self-confidence in gaining employment
}

\begin{tabular}{|c|c|}
\hline \multicolumn{2}{|c|}{$\begin{array}{l}\text { Authors: } \\
\text { Melinde Coetzee }{ }^{1} \\
\text { Nadia Ferreira }^{2} \\
\text { Ingrid L. Potgieter }\end{array}$} \\
\hline \multicolumn{2}{|c|}{$\begin{array}{l}\text { Affiliations: } \\
\text { 'Department of Industrial } \\
\text { and Organisational } \\
\text { Psychology, College of } \\
\text { Economic and Management } \\
\text { Sciences, University of South } \\
\text { Africa, Pretoria, South Africa }\end{array}$} \\
\hline \multicolumn{2}{|c|}{$\begin{array}{l}{ }^{2} \text { Department of Human } \\
\text { Resource Management, } \\
\text { College of Economic and } \\
\text { Management Sciences, } \\
\text { University of South Africa, } \\
\text { Pretoria, South Africa }\end{array}$} \\
\hline \multicolumn{2}{|c|}{$\begin{array}{l}\text { Corresponding author: } \\
\text { Melinde Coetzee, } \\
\text { coetzm1@unisa.ac.za }\end{array}$} \\
\hline \multicolumn{2}{|c|}{$\begin{array}{l}\text { Received: } 14 \text { July } 2019 \\
\text { Accepted: } 28 \text { Aug. } 2019 \\
\text { Published: } 09 \text { Oct. } 2019\end{array}$} \\
\hline \multicolumn{2}{|c|}{$\begin{array}{l}\text { How to cite this article: } \\
\text { Coetzee, M., Ferreira, N., \& } \\
\text { Potgieter, I.L. (2019). } \\
\text { Employer requirements and } \\
\text { employability mindsets } \\
\text { influencing graduate workers' } \\
\text { self-confidence in gaining } \\
\text { employment. African Journal } \\
\text { of Career Development 1(1), } \\
\text { a4. https://doi.org/10.4102/ } \\
\text { ajcd.v1i1.4 }\end{array}$} \\
\hline \multicolumn{2}{|c|}{$\begin{array}{l}\text { Copyright: } \\
\text { (c) 2019. The Author } \\
\text { Licensee: AOSIS. This } \\
\text { is licensed under the } \\
\text { Creative Commons } \\
\text { Attribution License. }\end{array}$} \\
\hline \multicolumn{2}{|l|}{ Read online: } \\
\hline 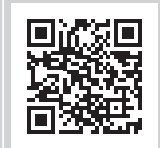 & $\begin{array}{l}\text { Scan this QR } \\
\text { code with your } \\
\text { smart phone or } \\
\text { mobile device } \\
\text { to read online. }\end{array}$ \\
\hline
\end{tabular}

Background: Little is known about when (under which mindset conditions) graduate workers' self-confidence in gaining employment increases.

Objective: The current study explored the interaction effects between employers' importance attached to graduate workers' graduateness and employability qualities, and graduate workers' mindsets of marketability, entrepreneurial orientation and networking or job search orientation in predicting their self-confidence in gaining employment.

Method: The study was exploratory and cross-sectional in nature, involving $(N=153)$ predominantly black African (71\%) graduate-level workers employed in the South African services industry.

Results: Hierarchical moderated regression analysis showed significant moderation effects on the mindsets of entrepreneurial orientation and marketability.

Conclusion: The findings added new insights to the employability research literature by introducing the influencing role of the prospective employee's own mindset in raising intrinsic self-confidence in gaining employment, while also triggering extrinsic self-confidence in employability in the link with employers' requirements for graduateness and employability qualities.

Keywords: Employability; graduate worker; graduateness; employability qualities; mindsets of employability; marketability; entrepreneurial orientation; networking/job search behaviour; self-confidence in gaining employment.

\section{Significance of work}

In the current study, we add new knowledge to the existing literature on graduate workers' employability. The objective is to explore the interaction effects between employers' importance attached to graduate workers' graduateness and employability qualities, and graduate workers' mindset regarding marketability, entrepreneurial orientation and networking or job search orientation in predicting their self-confidence in gaining employment. Our study extends research on the role of graduate worker's graduateness and employability qualities in their employability. We go beyond the study of mere skills and personal qualities to make a new contribution to the research literature through our exploration of the mindset conditions that influence individuals' self-confidence in gaining employment. Specifically, the findings added new insights to the employability research literature by introducing the influencing role of professional purposeful mindsets such as entrepreneurial orientation and marketability in raising intrinsic self-confidence in gaining employment, while also triggering extrinsic self-confidence in employability in the link with employers' requirements for graduateness and employability qualities. As such, our research fills an important gap in the employability research literature.

\section{Background}

Prolific changes in the professional world along with the competition for graduate jobs have become fierce in an economic climate characterised by high levels of uncertainty and unemployment (Beaumont, Gedye, \& Richardson, 2016; Maree, 2019). The ability to find and/or create a job or some form of employment is an integral aspect of individuals' careers and psychological wellbeing (Baruch, 2017; De Cuyper, Van Den Broeck, \& De Witte, 2017). Research indicates graduate adult workers' self-confidence as a key barrier in gaining sustained employment (Beaumont et al., 2016; Dacre Pool \& Sewell, 2007; Norman \& Hyland, 2003; Yorke \& Knight, 2007). Scholars in the field of careers and employability suggest that people with self-confidence are able to successfully 
present their employability qualities and graduateness in situations such as job searching (Dacre Pool \& Sewell, 2007; Kim, Kim, \& Lee, 2015; Onyishi, Enwereuzor, Ituma, \& Omenma, 2015). It is therefore argued that increasing adult workers' self-confidence is an important motivational strategy for facilitating a sustainable career and livelihood in a complex employment market (Beaumont et al., 2016; Qenani, MacDougall, \& Sexton, 2014).

In the context of the present research, adult workers are seen as career actors who participate in the career ecosystem (Baruch, 2017). Within the career ecosystem, employers represent the internal labour market that generally offers, through employment in an organisation, the psychological space within which the adult worker's career and personal development unfolds and evolves (Baruch, 2017). Adult workers have come to understand that there is neither career stability nor a promise of future employment. They have also come to realise that their ability to craft a meaningful livelihood relies on their ability to confidently grow and develop, and adapt and adjust to an ever-changing labour and work environment (Baruch, 2017). Moreover, adult workers increasingly regard employers' perceptions of their graduateness (i.e. the quality of personal growth and intellectual development of the graduate; Barrie, 2004; Coetzee, 2012) and employability qualities (i.e. personal attributes and skills that provide the individual with a competitive advantage in the labour market; Finch, Peacock, Levalett, \& Foster, 2016) as important factors to consider for their sustainable participation in the labour market. According to Clarke (2018), working adults have become more concerned about sustainable employability themselves. It appears that the effects of the labour market's inconsistency and competitiveness have been compounded by greater levels of job insecurity. These conditions seemed to have weakened working adults' confidence in terms of finding a job or employment (Clarke, 2018). Some factors that were shown to influence individuals' confidence in gaining employment include employers' competition for highly qualified graduates with strong employability qualities, the need for graduates with work experience, employers' perceptions of the quality of the degree, individuals' graduateness and academic qualifications, economic conditions and individuals' selfconfidence in gaining employment (Beaumont et al., 2016; Coetzee, 2012). However, more knowledge is needed about the mindset conditions that may contribute to an individuals' selfconfidence in gaining employment (Beaumont et al., 2016).

Employability research is regarded as an emergent and crucial research area with the bulk of studies published after the year 2000 (McArthur, Kubacki, Pang, \& Alcaraz, 2017). Research on links between perceived employability and other factors such as self-efficacy, self-confidence, personal employability skills and education and academic qualifications has been evident in the employability literature (Beaumont et al., 2016; Dacre Pool \& Sewell, 2007; Finch et al., 2016; Kim et al., 2015; Onyishi et al., 2015). Exploratory research also shows links between adult workers' graduateness and their employability prospects (Franham, 2017; Moolman, 2016; Sin \& Amaral, 2017; Tomlinson \& Holmes, 2017). However, more research is needed to gain deeper insight into the mindset regarding employability that explains an individual's self-confidence in finding or creating a job or form of employment. Unfortunately, little is known about when (under which employability mindset conditions) individuals' self-confidence in gaining employment increases.

In the present study, we explore the interaction effects between two employer variables (perceived importance attached to the adult worker's graduateness and employability qualities), and three individual employability mindset conditions as moderating variables (perceived marketability, perceived entrepreneurial orientation and networking or job search orientation) in predicting higher levels of self-confidence in gaining employment. We propose that a positive link between perceived employers' importance attached to the adult worker's graduateness and employability qualities and the worker's enhanced levels of self-confidence in gaining employment is conditional upon high levels of perceived marketability, perceived entrepreneurial orientation and networking or job search orientation. Below, we discuss the various constructs, highlighting the untested assumptions concerning the moderating role of perceived marketability, perceived entrepreneurial orientation and networking or job search orientation by presenting the conceptual research model. We then discuss the research method applied in testing the interaction effects of the employer and individual variables in explaining individuals' self-confidence in gaining employment.

\section{Employer requirements for graduateness and employability qualities}

The present study focuses on perceived employers' importance attached to employees' graduateness and employability qualities. Graduateness relates to employers' perceptions of the quality of personal growth and intellectual development employees acquired through their graduate academic studies (Barrie, 2004; Coetzee, 2012). A worker's graduateness enhances the ability to find an employment opportunity, use it and become a valued employee (Franham, 2017; Moolman, 2016; Sin \& Amaral, 2017; Tomlinson \& Holmes, 2017). Some of the attributes that employers regard as important indications of graduateness include the ability to quickly acquire new knowledge; being educated, trained and proficient in the relevant occupational field; having jobspecific knowledge and skills; the ability to apply universal, global knowledge, principles, philosophies and paradigms to solve job or work challenges; the ability to communicate in English; and the ability to work in teams with people from culturally diverse backgrounds (Coetzee, 2012, 2018).

Employability qualities relate to personal attributes or traits that characterise a person, either innate or learned, but typically not taught by university. These 'soft skills' are often in higher demand than occupational skills and provide the individual with a competitive advantage in the labour market (Finch et al., 2016; McArthur et al., 2017). The employability 
qualities that are regarded as important by employers include a range of abilities pertaining to being able to work under pressure; managing and using time efficiently or productively; adapting to changing conditions; following through and delivering results; keeping one's knowledge and skills relevant and updated; being client or customer service oriented; managing one's own career development; and engaging in continuous life-long learning activities (Chhinzer \& Russo, 2018; Coetzee, 2018; Finch et al., 2016).

Rapid transformation of work and an extremely competitive labour market have transformed the nature of employers' requirements for workers' employability. The primary reason employers increasingly demand working adults with high levels of graduateness and sustainable employability qualities is attributed to factors such as the change in the economy, the increase in globalisation and the need for a highly skilled workforce to deal with the current and future global technology-driven business market challenges (Bates, Rixon, Carbone, \& Pilgrim, 2019; Clarke, 2018; Clements \& Kamau, 2017). From the employers' viewpoint, skilled working adults with a high level of graduateness are seen as key role players who add value to products and services (Tomlinson \& Holmes, 2017). Employability is viewed as part of a new kind of psychological contract, and employers continue to recognise the importance of investing in, and increasing the academic-level qualification and graduateness, as well as the employability qualities of employees through education, training and development efforts (Bernstrom, Drage, \& Mamelund, 2019).

Workers' graduateness represents their intellectual resources, which, when successfully combined with employability qualities, maximise their value for employers and differentiate them from other graduate workers (Finch et al., 2016). Previous research demonstrates a strong link between the intellectual resources (denoted by individuals' graduateness) and their employability across a variety of occupations and contexts (Finch et al., 2016; Scherbaum, Goldstein, Yusko, Ryan, \& Hanges, 2012; Stiwne \& Jungert, 2010). Research also shows that workers who display both graduateness and employability qualities signal enhanced employability to employers (Coetzee, 2012; Finch et al., 2016).

\section{Individuals' marketability, entrepreneurial orientation and networking or job search orientation}

Gaining and sustaining employment is an important career outcome. Individuals' mindsets about their careers guide their approach to managing the complexities of both the external labour market and the internal labour market represented by the organisation (Baruch, 2017; Bates et al., 2019). A mindset denotes a predisposition to perceive and reason in certain ways which creates certain psychosocial conditions that influence individuals' employability confidence (Bates et al. 2019). Bates et al. (2019) propose the notion of a professional, career-specific and purposeful, driving the need to develop personal resources that enable the pursuit of career goals in the employability context. Bates et al. (2019) argue that the concept of a professional purposeful mindset extends the notion of employability beyond the limitations of a purely skills- or attributes-based approach (i.e. as denoted by an individual's graduateness and employability qualities).

Drawing from the theory of Bates et al. (2019), the three constructs of marketability, entrepreneurial orientation and networking or job search orientation are regarded as an important, generalised, professional, purposeful, employability-related mindsets in career self-management and job or employment search behaviour. Building further on the basic premises of Bates et al.'s (2019) theory, we propose that the three mindsets (i.e. marketability, entrepreneurial orientation and networking or job search orientation) reflect individuals' intrinsic motivation to purposefully engage in behaviours that support the development of a professional future that is personally meaningful to them. These behaviours function as important mindset conditions that enhance self-confidence in finding or creating a job or form of employment. In the context of the present research, it is argued that employers' importance attached to graduate worker's graduateness and employability qualities will positively contribute to higher levels of self-confidence in gaining employment when the purposeful mindset conditions of marketability, entrepreneurial orientation and networking or job search orientation are present. As such, we formulated the following two research hypotheses:

H1: The relationship between employers' importance attached to graduateness and individuals' self-confidence in gaining employment will be moderated by individuals' mindsets of marketability, entrepreneurial orientation and networking or job search orientation, such that the relationship will be positive under conditions of high mindsets levels, and negative under conditions of low mindset levels.

H2: The relationship between employers' importance attached to employability qualities and individuals' self-confidence in gaining employment will be moderated by individuals' mindsets of marketability, entrepreneurial orientation and networking or job search orientation, such that the relationship will be positive under conditions of high mindsets levels and negative under conditions of low mindset levels.

Figure 1 provides a conceptual overview of the research model.

Marketability relates to beliefs about the labour market's view of the credibility of one's qualification, and the acceptability and relevance of one's mix of personal qualities, competencies and work experience. Individuals' entrepreneurial orientation reflects their beliefs about their ability to find or create a job or employment through their entrepreneurial competencies. The mindset of proactivity in networking and job search behaviours involves beliefs about the importance of purposeful, active engagement in activities that broaden one's employability scope. Such beliefs include, for example, one's proactivity in networking with professional societies and communities, attending conferences and seminars and using social networks or the Internet to actively search for 


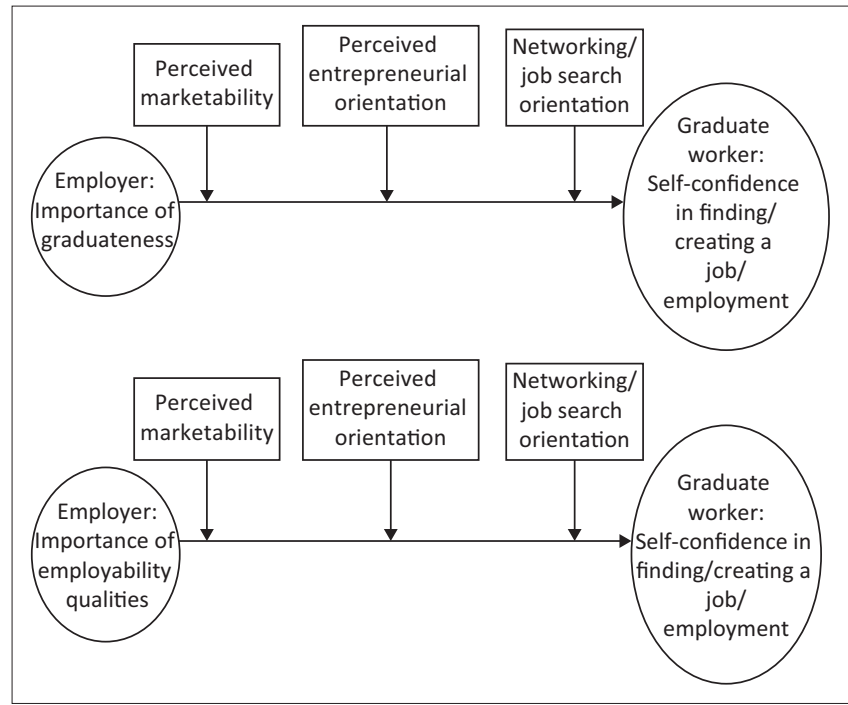

FIGURE 1: Conceptual model of the research: Interaction effects of predictors of graduate workers' self-confidence in finding or creating a job or employment.

employment opportunities and familiarise oneself with employer requirements and market trends (Coetzee, 2018).

The literature highlights networking, entrepreneurial orientation and marketability as important mindsets for sustained employability (Bates et al., 2019; Bridgstock, GrantIramu, \& MsAlpine, 2019; Jorre De St Jorre, Elliott, Johnson, \& Bisset, 2019). In similar vein, we argue that the mindset of marketability alludes to beliefs about having a competitive advantage as a graduate because of the credibility and quality of one's degree and the personal qualities, skills and experience one obtained through one's higher education studies. We propose that this belief may be associated with higher levels of self-confidence in gaining employment. The mindsets of entrepreneurial orientation and networking or job search orientation allude to the use of entrepreneurial thought and social networks and resources (i.e. social influencing and relational capital) that drive employability and the achievement of professional purpose career goals. Drawing from the theory of Bates et al. (2019), both of these two mindsets also reflect a degree of proactive curiosity and exploratory behaviours which may help reduce uncertainty and drive employability confidence. As such, we propose that these two mindsets will also be associated with higher levels of self-confidence in gaining employment. Research has also shown positive links between social or relational career capital and perceived internal and external marketability and career success (Dickmann, Vesa, \& Wurtz, 2018; Latzke, Schneidhofer, Pernkopf, Rohr, \& Mayrhofer, 2015).

\section{Objective of the research}

In the current study, we seek to add to the existing literature on graduate workers' employability. The objective is to explore the interaction effects between employers' importance attached to graduate workers' graduateness and employability qualities, and graduate workers' mindsets of marketability, entrepreneurial orientation and networking or job search orientation in predicting their self-confidence in gaining employment. Our study extends research on the role of graduate worker's graduateness and employability qualities in their employability. We go beyond the study of mere skills and personal qualities to make a new contribution to the research literature through our exploration of the mindset conditions that influence individuals' self-confidence in gaining employment. As such, our research fills an important gap in the employability research literature.

\section{Method Participants}

The sample was represented by $(N=153)$ predominantly black African (71\%) graduate-level workers employed in the South African services industry. White people (18\%), mixed races $(8 \%)$ and Asians (3\%) were in the minority. The participants were pursuing a postgraduate qualification in industrial and organisational psychology and human resource management through an open and distance learning higher education institution. Female participants represented $69 \%$ of the sample (male participants $=31 \%$ ). The mean age of the participants was 38 years $(\mathrm{SD}=9.15)$.

\section{Measuring instruments}

The graduateness or employability survey instrument developed by Coetzee (2018) was used to measure the following constructs: self-confidence in finding or creating a job or employment (overall construct measured on a fourpoint Likert type scale: 1 = not confident; 4 = highly confident); perceived marketability (five items; e.g. 'I have the right personal qualities that employers are looking for') and perceived entrepreneurial orientation (five items; e.g. 'My entrepreneurial competencies help me in finding or creating employment') measured on a four-point Likert type scale ( $1=$ not at all; $4=$ definitely); perceived networking or job searching orientation (four items; e.g. 'I use the social network or Internet to search for employment opportunities, and familiarise myself with employer requirements'); and employer perception of: (1) importance of graduateness (10 items; e.g. 'Being proficient in your occupational field'); and (2) personal employability qualities (eight items, e.g. 'Ability to keep your knowledge and skills updated and relevant') measured on a fivepoint Likert type scale ( $1=$ very low importance; $5=$ very high importance). Initial construct validity has been established by means of exploratory factor analysis and confirmatory factor analysis (Coetzee, 2018). Internal consistency reliabilities for the various subscales ranged between 0.60 and 0.90 .

\section{Procedure}

Data were collected by means of an online web survey to which participants received an electronic link via email. Responses were captured on an Excel spreadsheet and converted into an SPSS (Statistical Package for the Social Sciences) file for data analysis purposes. 


\section{Ethical consideration}

Ethical clearance and permission to conduct the research were obtained from the management of the research institution (Ethics certificate: Ref\#:2018_CRERC_004 FA). The participants were invited to voluntarily participate in the research study. The online questionnaire included an informed consent form. The privacy, anonymity and confidentiality of all the participants were ensured and honoured. The participants gave informed consent that the data could be used for research purposes.

\section{Data analysis}

A regression-based hierarchical moderated analysis using the PROCESS version 3.00 for SPSS procedure developed by Hayes (2018) was performed to test the research model. The Preacher and Hayes (2008) bootstrapping procedure (bootstrap samples $=5000$ ) was applied to test the proposed conditional indirect effects. Bootstrapping is a more stringent bias-correcting procedure that involves resampling and building a non-normal sampling distribution of the indirect effect from which confidence intervals can be constructed.

This approach reduces the likelihood of Type I error (Hayes, 2013, 2015, 2018; Preacher \& Hayes, 2008). The 95\% lower and upper confidence interval levels (LLCI and ULCI) were used as threshold for examining the significance of direct and indirect effects. Following the guidelines of Shrout and Bolger (2002), LLCI and ULCI ranges that did not include zero, provided evidence of significant direct and indirect effects. Concerns about multicollinearity were addressed by using mean-centred values for the predictor variables before computing the interaction terms in accordance with the guidelines of Aiken and West (1991). Tolerance (less than 0.1) and the variance inflation factor (VIF), above 2.5 , were also utilised to assess multicollinearity concerns.

\section{Results}

Table 1 reports the descriptive statistics and bivariate correlations. The internal consistency reliability coefficients ranged between 0.60 and 0.90 . The Cronbach's reliability coefficients of 0.60 (perceived entrepreneurial orientation) and 0.65 (confidence in finding or creating a job or employment) were below the threshold value of 0.70 .

However, because of the broad, exploratory group-based nature of the research design, the reliability of the subscales was considered adequate for research purposes.
The significant positive bivariate correlations ranged between $r \geq 0.16$ and $r \leq 0.55$ ( $p \leq 0.05$; small to large practical effect). Perceived employer's importance of graduateness and employability qualities did not correlate significantly with perceived network or job search orientation.

Tables 2 and 3 report the hierarchical moderated regression analysis, while Figures 1-3 illustrate the significant interaction effects.

\section{Moderated regression results: Interaction effects between employer's importance of graduateness, and marketability, entrepreneurial orientation and networking or job search orientation in predicting self-confidence in finding or creating a job or employment}

Table 2 shows the three models that were computed to test the interaction effects between perceived employer's importance attached to graduateness and the three moderating variables (perceived marketability, perceived entrepreneurial orientation and networking or job search orientation) in predicting self-confidence in finding or creating a job or employment.

All three analysis of variance (ANOVA) models were significant: model 1: $F=5.62 ; p \leq 0.0001$; model $2: F=9.43$; $p \leq 0.0001$; model 3: $F=5.20 ; p \leq 0.01$. The practical effect of the models was small $\left(R^{2} \leq 0.10\right)$. Only model 2 (with moderating variable perceived entrepreneurial orientation) showed a significant interaction effect: $\Delta F p=5.23 ; p=0.05$; $\Delta R^{2}=0.03$; small practical effect; $f^{2}=0.19$; moderate practical effect). Table 2 further shows that the independent variable and moderating variables had significant main effects on the dependent variable.

Figure 2 illustrates the significant interaction effects between perceived employer's importance attached to graduateness and adult workers' perceived entrepreneurial orientation in predicting their self-confidence in finding or creating a job or employment. It is evident from Figure 2 that those participants who had high perceived entrepreneurial orientation and who also perceived employers to attach high importance to their graduateness had significant high levels of self-confidence in finding or creating a job or employment. Those participants who perceived employers to attach low importance to their graduateness, and who had low levels of perceived entrepreneurial orientation, had also significantly low levels

TABLE 1: Descriptive statistics and bivariate correlations $(N=153)$.

\begin{tabular}{|c|c|c|c|c|c|c|c|c|c|c|}
\hline Variable numbering & Variable & Mean & SD & $\alpha$ & 1 & 2 & 3 & 4 & 5 & 6 \\
\hline 1 & Self-confidence in finding or creating a job or employment & 3.08 & 0.46 & 0.65 & - & - & - & - & - & - \\
\hline 2 & Perceived marketability & 3.50 & 0.50 & 0.71 & $0.30 * * *$ & - & - & - & - & - \\
\hline 3 & Perceived entrepreneurial orientation & 2.66 & 0.55 & 0.60 & $0.31 * * *$ & $0.54 * * *$ & - & - & - & - \\
\hline 4 & Perceived networking or job search orientation & 2.36 & 0.78 & 0.70 & $0.24 * *$ & $0.25 * *$ & $0.28 * * *$ & - & - & - \\
\hline 5 & Importance of graduateness & 4.44 & 0.47 & 0.89 & $0.22 * *$ & $0.23 * *$ & $0.16^{*}$ & 0.06 & - & - \\
\hline 6 & Importance of employability qualities & 4.46 & 0.49 & 0.90 & $0.23 * *$ & $0.33 * * *$ & $0.25 * *$ & 0.04 & $0.78 * *$ & - \\
\hline
\end{tabular}

$\mathrm{SD}$, standard deviation; $\alpha$, alpha.

$*, p \leq 0.05 ; * *, p \leq 0.01 ; * * *, p \leq 0.001$. 
TABLE 2: Moderated regression results: Interaction effects between employer's importance of graduateness, and marketability, entrepreneurial orientation and networking or job search orientation as predictors of self-confidence in finding or creating a job or employment $(N=153)$.

\begin{tabular}{|c|c|c|c|c|c|c|}
\hline \multirow[t]{2}{*}{ Model } & \multicolumn{3}{|c|}{ Coefficient estimates } & \multicolumn{2}{|c|}{ Bootstrap $95 \% \mathrm{Cl}$} & \multirow[t]{2}{*}{ Model info } \\
\hline & $\beta$ & SE & $t$ & LLCI & ULCI & \\
\hline \multicolumn{7}{|c|}{ Model 1: Outcome: Self-confidence in finding or creating a job or employment, or even better employment than your current job } \\
\hline Constant & 61.56 & 2.73 & $22.59 * * *$ & 56.17 & 66.94 & - \\
\hline Importance of graduateness (employer perception) $(A)$ & 14.42 & 5.91 & $2.44 *$ & 2.75 & 26.10 & - \\
\hline Perceived marketability $(B)$ & 14.31 & 5.44 & $2.63 * *$ & 3.56 & 25.06 & - \\
\hline Interaction term: $A \times B$ & 13.45 & 12.71 & 1.06 & -11.67 & 38.58 & - \\
\hline$F p$ & - & - & - & - & - & $5.62 * * *$ \\
\hline$R^{2}$ & - & - & - & - & - & 0.10 \\
\hline$\Delta R^{2}$ & - & - & - & - & - & 0.01 \\
\hline$\Delta F p$ & - & - & - & - & - & 1.12 \\
\hline \multicolumn{7}{|c|}{ Model 2: Outcome: Self-confidence in finding or creating a job or employment, or even better employment than your current job } \\
\hline Constant & 61.26 & 2.60 & $23.56 * * *$ & 56.12 & 66.40 & - \\
\hline Importance of graduateness (employer perception) $(A)$ & 13.56 & 5.61 & $2.42 *$ & 2.47 & 24.64 & - \\
\hline Perceived entrepreneurial orientation $(B)$ & 15.91 & 4.77 & $3.34 * * *$ & 6.48 & 25.34 & - \\
\hline$F p$ & - & - & - & - & - & $9.43 * * *$ \\
\hline$R^{2}$ & - & - & - & - & - & 0.16 \\
\hline$\Delta R^{2}$ & - & - & - & - & - & 0.03 \\
\hline$\Delta F p$ & - & - & - & - & - & $5.23 *$ \\
\hline$f^{2}$ & & & & & & 0.19 \\
\hline \multicolumn{7}{|c|}{ Model 3: Outcome: Self-confidence in finding or creating a job or employment, or even better employment than your current job } \\
\hline Constant & 61.95 & 2.68 & $23.14 * * *$ & 56.66 & 67.24 & - \\
\hline Importance of graduateness (employer perception) $(A)$ & 16.30 & 5.80 & $2.81 * *$ & 4.83 & 27.76 & - \\
\hline Networking or job search orientation $(B)$ & 8.01 & 3.47 & $2.31 *$ & 1.15 & 14.86 & - \\
\hline Interaction term: $A \times B$ & 8.49 & 7.81 & 1.09 & -6.95 & 23.94 & - \\
\hline$F p$ & - & - & - & - & - & $5.20 * *$ \\
\hline$R^{2}$ & - & - & - & - & - & 0.10 \\
\hline$\Delta R^{2}$ & - & - & - & - & - & 0.01 \\
\hline$\Delta F p$ & - & - & - & - & - & 1.18 \\
\hline
\end{tabular}

$*, p \leq 0.05 ; * *, p \leq 0.01 ; * * *, p \leq 0.001$

$\mathrm{Cl}$, confidence interval; LLCI, lower level confidence interval; ULCI, upper level confidence interval; SE, standard error.

of self-confidence in their ability to find or create a job or employment.

The results provided partial evidence in support of Hypothesis 1: The relationship between employers' importance attached to graduateness and individuals' self-confidence in gaining employment will be moderated by individuals' mindsets of marketability, entrepreneurial orientation and networking or job search orientation, such that the relationship will be positive under conditions of high mindsets levels, and negative under conditions of low mindset levels.

\section{Moderated regression results: Interaction effects between employer's importance of employability qualities, and marketability, entrepreneurial orientation and networking or job search orientation as predictors of self-confidence in finding or creating a job or employment}

Table 3 shows the three models that were computed to test the interaction effects between perceived employer's importance attached to employability qualities and the three moderating variables (perceived marketability, perceived entrepreneurial orientation and networking or job search orientation) in predicting self-confidence in finding or creating a job or employment.
All three ANOVA models were significant: model 1: $F=5.64$; $p \leq 0.0001$; model 2: $F=8.42 ; p \leq 0.0001$; model 3: $F=3.57$; $p \leq 0.05$. The practical effect of the models was small to moderate $\left(R^{2} \leq 0.15\right)$. Model 1 (with moderating variable perceived marketability) showed a significant interaction effect: $\Delta F p=5.59 ; p=0.05 ; \Delta R^{2}=0.04$; small practical effect; $f^{2}=0.12$; small practical effect). Model 2 (with moderating variable perceived entrepreneurial orientation) showed a significant interaction effect: $\Delta F p=7.31 ; p=0.01 ; \Delta R^{2}=0.04$; small practical effect; $f^{2}=0.18$; moderate practical effect). Table 2 further shows that the independent variable had no significant main effect on the dependent variable, while the three moderating variables had a significant main effect on the dependent variable.

Figure 3 illustrates the significant interaction effects between perceived employer's importance attached to employability qualities and adult workers' marketability in predicting their self-confidence in finding or creating a job or employment. It is evident from Figure 3 that those participants who had high perceived marketability and who also perceived employers to attach high importance to their employability qualities had significant high levels of self-confidence in finding or creating a job or employment. Those participants who perceived employers to attach low importance to their employability qualities, and who had low levels of perceived marketability, had also significantly 
TABLE 3: Moderated regression results: Interaction effects between employer's importance of employability qualities, and marketability, entrepreneurial orientation and networking or job search orientation as predictors of self-confidence in finding or creating a job or employment $(N=153)$.

\begin{tabular}{|c|c|c|c|c|c|c|}
\hline \multirow[t]{2}{*}{ Model } & \multicolumn{3}{|c|}{ Coefficient estimates } & \multicolumn{2}{|c|}{ Bootstrap $95 \% \mathrm{Cl}$} & \multirow[t]{2}{*}{ Model info } \\
\hline & $\beta$ & SE & $t$ & LLCl & ULCl & \\
\hline \multicolumn{7}{|c|}{ Model 1: Outcome: Self-confidence in finding or creating a job or employment, or even better employment than your current job } \\
\hline Constant & 60.15 & 2.80 & $21.52 * * *$ & 54.62 & 65.67 & - \\
\hline Importance of employability qualities (employer perception) $(A)$ & 9.54 & 6.01 & 1.59 & -2.34 & 21.43 & - \\
\hline Perceived marketability $(B)$ & 15.97 & 5.65 & $2.83 * *$ & 4.80 & 27.14 & - \\
\hline Interaction term: $A \times B$ & 25.42 & 10.75 & $2.36 *$ & 4.16 & 46.67 & - \\
\hline$F p$ & - & - & - & - & - & $5.64 * * *$ \\
\hline$R^{2}$ & - & - & - & - & - & 0.11 \\
\hline$\Delta R^{2}$ & - & - & - & - & - & 0.04 \\
\hline$\Delta F p$ & - & - & - & - & - & $5.59 *$ \\
\hline$f^{2}$ & - & - & - & - & - & 0.12 \\
\hline \multicolumn{7}{|c|}{ Model 2: Outcome: Self-confidence in finding or creating a job or employment, or even better employment than your current job } \\
\hline Constant & 60.30 & 2.69 & $22.46 * * *$ & 54.99 & 65.60 & - \\
\hline Importance of employability (employer perception) $(A)$ & 9.38 & 5.67 & 1.65 & -1.84 & 20.59 & - \\
\hline Interaction term: $A \times B$ & 27.96 & 10.35 & $2.70 * *$ & 7.51 & 48.41 & - \\
\hline$F p$ & - & - & - & - & - & $8.42 * * *$ \\
\hline$R^{2}$ & - & - & - & - & - & 0.15 \\
\hline$\Delta R^{2}$ & - & - & - & - & - & 0.04 \\
\hline$\Delta F p$ & - & - & - & - & - & $7.31 * *$ \\
\hline$f^{2}$ & - & - & - & - & - & 0.18 \\
\hline \multicolumn{7}{|c|}{ Model 3: Outcome: Self-confidence in finding or creating a job or employment, or even better employment than your current job } \\
\hline Constant & 62.22 & 2.71 & $22.96 * * *$ & 56.86 & 67.57 & - \\
\hline Importance of employability qualities (employer perception) $(A)$ & 11.002 & 5.62 & 1.96 & -0.10 & 22.10 & - \\
\hline Networking or job search orientation $(B)$ & 8.94 & 3.50 & $2.56 * *$ & 2.03 & 15.85 & - \\
\hline Interaction term: $A \times B$ & -2.67 & 6.06 & -0.44 & -14.65 & 9.32 & - \\
\hline$F p$ & - & - & - & - & - & $3.57^{*}$ \\
\hline$R^{2}$ & - & - & - & - & - & 0.07 \\
\hline$\Delta R^{2}$ & - & - & - & - & - & 0.001 \\
\hline$\Delta F p$ & - & - & - & - & - & 0.19 \\
\hline
\end{tabular}

low levels of self-confidence in their ability to find or create a job or employment.

Figure 4 illustrates the significant interaction effects between perceived employer's importance attached to employability qualities and adult workers' perceived entrepreneurial orientation in predicting their self-confidence in finding or creating a job or employment. It is evident from Figure 4 that those participants who had high perceived entrepreneurial orientation and who also perceived employers to attach high importance to their employability qualities had significant high levels of selfconfidence in finding or creating a job or employment.

Those participants who perceived employers to attach low importance to their employability qualities, and who had low levels of perceived entrepreneurial orientation, had also significantly low levels of self-confidence in their ability to find or create a job or employment.

The results provided partial evidence in support of Hypothesis 2: The relationship between employers' importance attached to employability qualities and individuals' self-confidence in gaining employment will be moderated by an individuals' mindsets of marketability, entrepreneurial orientation and networking or job search orientation, such that the relationship will be positive under conditions of high mindsets levels, and negative under conditions of low mindset levels.

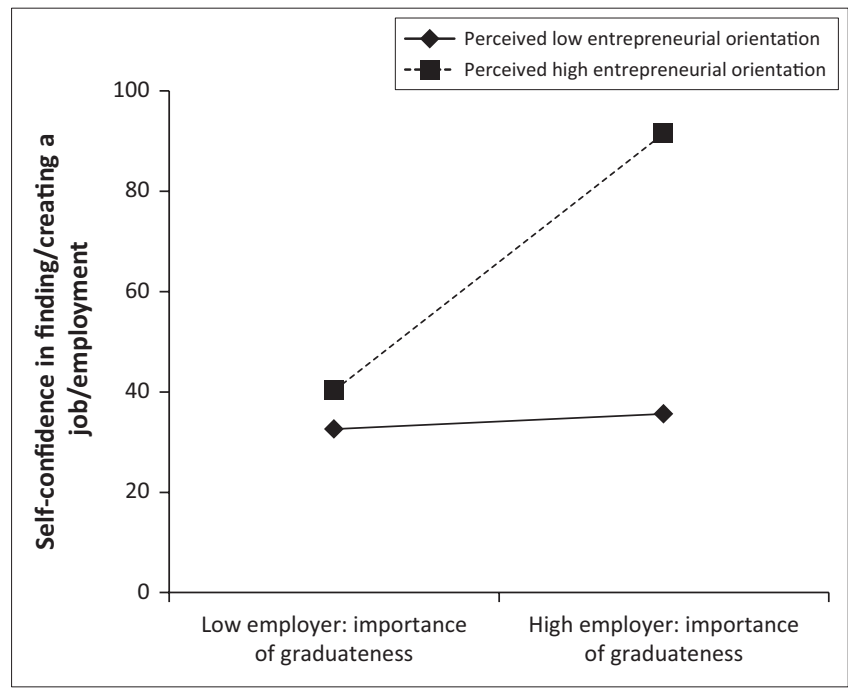

FIGURE 2: Interaction effects between perceived employer's importance of graduateness and perceived entrepreneurial orientation in predicting selfconfidence in finding or creating a job or employment.

\section{Discussion}

The study explored the interaction effects between employers' importance attached to graduate workers' graduateness and employability qualities, and their own mindsets of marketability, entrepreneurial orientation and networking or job search orientation in predicting their 


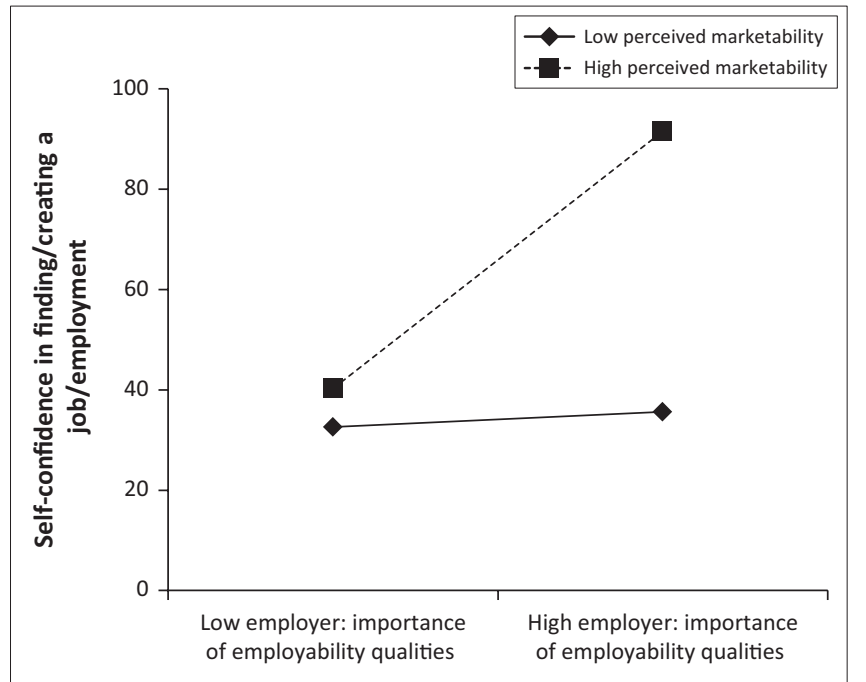

FIGURE 3: Interaction effects between perceived employer's importance of employability qualities and perceived marketability in predicting self-confidence in finding or creating a job or employment.

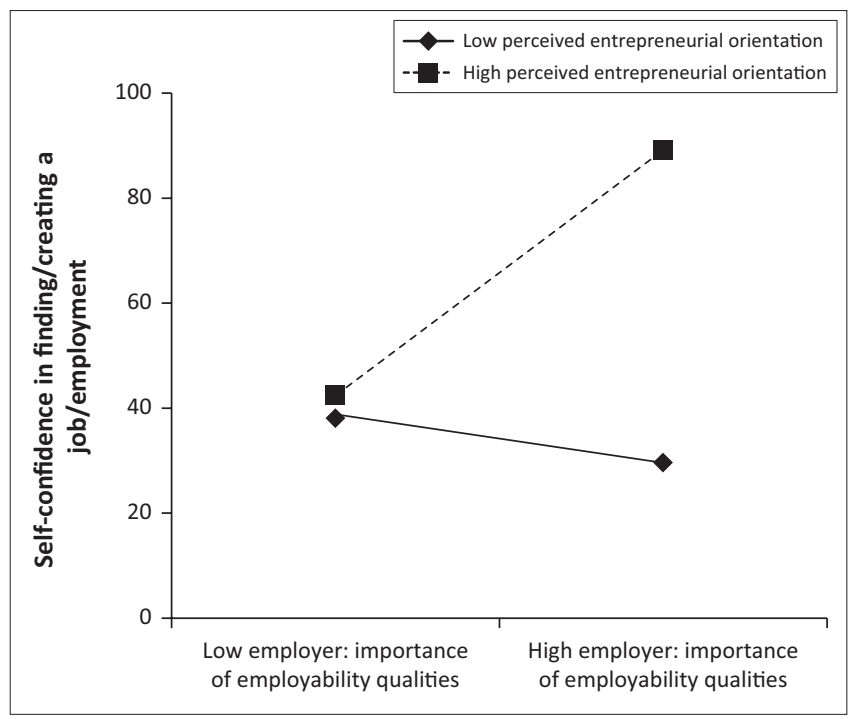

FIGURE 4: Interaction effects between perceived employer's importance of employability qualities and perceived entrepreneurial orientation in predicting self-confidence in finding or creating a job or employment.

self-confidence in gaining employment. The results showed that the professional purpose mindset of entrepreneurial orientation significantly explained the positive link between perceived employers' importance attached to the participants' graduateness and employability qualities and their selfconfidence in finding or creating a job or form of employment.

Graduateness (employers' perceptions of the graduate workers' intellectual resources gained from postgraduate studies; Barrie, 2004; Coetzee, 2012) had both a main, and in interaction with the graduate worker's entrepreneurial thought, a positive effect on levels of self-confidence in gaining employment. Employability qualities had no main effect on participants' self-confidence. However, in the interaction with the professional purposeful mindset of entrepreneurial thought (orientation), higher levels of selfconfidence were positively explained. Drawing from the professional purposeful mindset theory of Bates et al. (2019), it appears that entrepreneurial thoughts about one's employability enhance both the extrinsic and intrinsic functions of self-confidence (Beaumont et al., 2016). Firstly, the mindset seems to create a psychosocial motivational condition that raises the extrinsic (i.e. others or employers' perceived confidence in the graduate worker's ability to gain employment) function of self-confidence in gaining employment. Secondly, an entrepreneurial orientation seems to trigger the intrinsic (i.e. link with the graduate worker's beliefs about successfully achieving personal career goals and plans) function of individuals' self-confidence. Research shows that a lack of extrinsic and intrinsic self-confidence limits individuals' employability ambitions and the actions they may take to improve their employment prospects (Beaumont et al, 2016). In this regard, the mindset of entrepreneurial thought seems an important condition for strengthening the motivation for, and self-confidence in sustained employability. Research also demonstrates strong links between a mix of intellectual resources (denoted by individuals' graduateness) and employability qualities in enhanced perceptions of employability (Coetzee, 2012; Finch et al., 2016; Scherbaum et al., 2012; Stiwne \& Jungert, 2010). The present study provided additional new insights by showing the role of entrepreneurial thought in further strengthening self-confidence in sustaining employability through employment.

The mindset of marketability also appears to trigger the extrinsic and intrinsic functions of self-confidence in the interaction effect between perceived employers' importance attach to employability qualities (i.e. extrinsic confidence) and self-confidence in gaining employment. Marketability denotes a belief (i.e. intrinsic self-confidence) in one's competitive advantage in the marketplace (i.e. having a credible qualification, and the right mix of personal qualities, competencies and work experience; Coetzee, 2018). Research also shows links between perceived internal and external marketability and career success (Dickmann et al., 2018; Latzke et al., 2015).

The findings added new insights to the employability research literature by introducing the influencing role of professional purposeful mindsets such as entrepreneurial orientation and marketability in raising intrinsic selfconfidence in gaining employment. The findings showed that these two mindsets are psychosocial conditions that may trigger extrinsic self-confidence in employability in the link between employers' requirements for graduateness and employability qualities. These findings may have implications for practice. Firstly, the findings may help explain why some graduate workers have low levels of self-confidence in finding or creating a job or employment. Secondly, the findings suggest that employers can help cultivate graduate workers' self-confidence in gaining or sustaining employment by developing professional purposeful mindsets of entrepreneurial thought about their employability and their marketability. In order for these motivational conditions to function effectively in raising self-confidence in employability, graduate workers 
also need to understand employers' requirements for graduateness and desirable employability qualities. Such awareness may help raise the extrinsic function of selfconfidence.

\section{Research limitations and directions for future research}

The potential implications for practice must be considered in light of the limitations of the current study. The relatively small sample size and cross-sectional exploratory research design of the study limits the generalisability of the findings. The study also involved postgraduate-level working adults from the South African organisational setting. The research design was appropriate for the exploratory nature of the research because little is known about when (under which employability mindset conditions) individuals' selfconfidence in gaining employment increases. Future studies could explore the constructs in various occupational and industry settings and from a longitudinal point of view to be able to assess cause and effect relations.

\section{Conclusion}

The study opens up avenues for gaining deeper insight into how employer requirements and employability mindset conditions explain individuals' self-confidence in finding or creating a job or form of employment. Non-withstanding the limitations of the research design, the present study helps foster an understanding of the role of important mindsets of professional purposefulness in employability research and practice.

\section{Acknowledgements Competing interests}

The authors have declared that no competing interests exist.

\section{Author's contributions}

All authors contributed to the data collection. M.C. assisted with the data analysis and interpretation. All authors contributed to the conceptual framework and writing up of the research article.

\section{Funding information}

This research received no specific grant from any funding agency in the public, commercial or not-for-profit sectors.

\section{Data availability statement}

Data sharing is not applicable to this article as no new data were created or analysed in this study.

\section{Disclaimer}

The views and opinions expressed in this article are those of the authors and do not necessarily reflect the official policy or position of any affiliated agency of the authors.

\section{References}

Aiken, L.S., \& West, S.G. (1991). Multiple regression: Testing and interpreting interactions. Thousand Oaks, CA: Sage.

Barrie, S.C. (2004). A research-based approach to generic graduate attributes policy. Higher Education Research \& Development, 23(3), 261-275. https://doi.org/ 10.1080/07294360.2012.642842

Baruch, Y. (2017). Organizational and labor markets as career ecosystem. In A. De Vos \& B.I.J.M. Van der Heijden (Eds.), Handbook of research on sustainable careers (pp. 364-380). Cheltenham: Edward Elgar.

Bates, G.W., Rixon, A., Carbone, A., \& Pilgrim, C. (2019). Beyond employability skills: Developing professional purpose. Journal of Teaching and Learning for Graduate Employability, 10(1), 7-26.

Beaumont, E., Gedye, S., \& Richardson, S. (2016). 'Am I employable?': Understanding students' employability confidence and their perceived barriers to gainin employment. Journal of Hospitality, Leisure, Sport, \& Tourism Education, 19, 1-9. https://doi.org/10.1016/j.jhlste.2016.06.001

Bernstrom, V.H., Drange, I., \& Mammelund, S. (2019). Employability as an alternative to job security. Personnel Review, 48(1), 234-248. https://doi.org/10.1108/PR-09-201702790.

Bridgstock, R., Grant-Iramu, M., \& McAlpine, A. (2019). Integrating career development learning into the curriculum: Collaboration with the careers service for employability. Journal of Teaching and Learning for Graduate Employability, 10(1), 56-72. https://doi.org/10.21153/jtlge2019vol10no1art785

Chhinzer, N., \& Russo, A.M. (2018). An exploration of employer perceptions of graduate student employability. Education + Training, 60(1), 104-120. https://doi. org/10.1108/ET-06-2016-0111

Clarke, M. (2018). Rethinking graduate employability: The role of capital, individual attributes and context. Studies in Higher Education, 43, 1923-1937. https://doi.org/ attributes and context. Studies in Highe
10.1080/03075079.2017.1294152

Clements, A.J., \& Kamau, C. (2018). Understanding students' motivation towards proactive career behaviours through goal-setting theory and the job-demands resources model. Studies in Higher Education, 43(12), 2279-2293. https://doi.org resources model. Studies in Higher
/10.1080/03075079.2017.1326022

Coetzee, M. (2012). A framework for developing student graduateness and employability in the economic and management sciences at the University of South Africa. In M. Coetzee, J. Botha, N. Eccles, N. Holtzhausen \& H. Nienaber (Eds.), Developing student graduateness and employability: Issues, provocations, theory and practical guidelines (pp. 119-152). Randburg: Knowres.

Coetzee, M. (2018). Graduateness/employability survey: Preliminary report. Unpublished Research Report, Department of Industrial and Organisational Psychology, University of South Africa, Pretoria, South Africa.

Dacre Pool, L., \& Sewell, P. (2007). The key to employability: developing a practical model of graduate employability. Education + Training, 49(4), 277-289. https:// doi.org/10.1108/00400910710754435

De Cuyper, N., Van Den Broeck, A., \& De Witte. (2017). Perceived employability in times of job insecurity. In A. De Vos \& B.I.J.M. Van Der Heijden (Eds.), Handbook of Research on Sustainable Careers (pp. 166-174). Cheltenham: Edward Elgar.

Dickmann, M., Vesa, S., \& Wurtz, O. (2018). The management of global careers: The rise of international work. London: Palgrave MacMillan. https://doi.org/ 10.1007/978-3-319-76529-7_1

Finch, D.J., Peacock, M., Levallet, N., \& Foster, W. (2016). A dynamic capabilities view of employability: Exploring the drivers of competitive advantage for university graduates. Education + Training, 58(1), 61-81, https://doi.org/10.1108/ET-02-2015-0013

Franham, J. (2017). Employability and higher education: The follies of the productivity challenge in the teaching excellence framework. Journal of Education Policy, 32(5), 628-641. https://doi.org/10.1080/02680939.2016.1268271

Hayes, A.F. (2013). An introduction to mediation, moderation, and conditional process analysis: A regression-based approach. New York: Guilford Press.

Hayes, A.F. (2015). An index and test of linear moderated mediation. Multivariate Behavioral Research, 50(1), 1-22. https://doi.org/10.1080/00273171.2014. 962683

Hayes, A.F. (2018). Introduction to mediation, moderation, and conditional process analysis (2nd edn.). New York: The Guilford Press.

Jorre de St Jorre, T., Elliott, J., Johnson, E.D., \& Bisset, S. (2019). Science students' conceptions of factors that will differentiate them in the graduate employment market. Journal of Teaching and Learning for Graduate Employability, 10(1), market. Journal of Teaching and Learning for Graduate
27-41. https://doi.org/10.21153/jtlge2019vol10no1art795

Kim, S., Kim, H., \& Lee, J. (2015). Employee self-concepts, voluntary learning behavior, and perceived employability. Journal of Managerial Psychology, 30(3), 264-279. https://doi.org/10.1108/JMP-01-2012-0010

Latzke, M., Schneidhofer, T.M., Pernkopf, K., Rohr, C., \& Mayrhofer, W. (2015). Relational career capital: Towards a sustainable perspective. In A. De Vos \& B.I.J.M. Van Der Heijden (Eds.), Handbook of research on sustainable careers (pp. 50-66). Cheltenham: Edward Elgar.

Maree, J.G. (2019). 2019 Theme: Career development in developing country contexts: A conduit to facilitate sustainable decent work for all, viewed 10 July 2019, from https://aosis.co.za/news-article/77.

McArthur, E., Kubacki, K., Pang, B., \& Alcaraz, C. (2017). The employers' view of 'work-ready' graduates: A study of advertisements for marketing jobs in Australia. Journal of Marketing Education, 39(2), 82-93. https://doi.org/10.1177/ 0273475317712766 
Moolman, H. (2016). A conceptual competence-based framework for enhancing the employability of graduates. The Independent Journal of Teaching and Learning, $12(2), 26-40$

Norman, M., \& Hyland, T. (2003). The role of confidence in lifelong learning. Educational Studies, 29(2-3), 261-272. https://doi.org/10.1080/03055690303275

Onyishi, I.E., Enwereuzor, I.K., Ituma, A.N., \& Omenma, J.T. (2015). The mediating role of perceived employability in the relationship between core self-evaluations and job search behavior. Career Development International, 20(6), 604-626. https:// doi.org/10.1108/CDI-09-2014-0130

Preacher, K.J., \& Hayes, A.F. (2008). Asymptotic and resampling strategies for assessing and comparing indirect effects in multiple mediator models. Behavior Research Methods, 40(3), 879-891. https://doi.org/10.3758/BRM. 40.3.879

Qenani, E., MacDougall, N., \& Sexton, C. (2014). An empirical study of self-perceived employability: Improving the prospects for student employment success in an uncertain environment. Active Learning in Higher Education, 15(3), 199-213. https://doi.org/10.1177/1469787414544875
Scherbaum, C.A., Goldstein, H.W., Yusko, K.P., Ryan, R., \& Hanges, P.J. (2012). Intelligence 2.0: Reestablshing a research program on $\mathrm{g}$ in I-O psychology.
Industrial and Organizational Psychology, 5(2), 128-148. https://doi.org/10.1111/ j.1754-9434.2012.01419.x

Shrout, P.E., \& Bolger, N. (2002). Mediation in experimental and non-experimental studies: New procedures and recommendations. Psychological Methods, 7(4), 422-445. https://doi.org/10.1037/1082-989X.7.4.422

Sin, C., \& Amaral, A. (2017). Academics' and employers' perceptions about responsibilities for employability and their initiatives towards its development. Higher Education, 73(1), 97-111. https://doi.org/10.1007/s10734-016-0007-y

Stiwne, E.E., \& Jungert, T. (2010). Engineering students' experiences of transition from study to work. Journal of Education and Work, 23(5), 417-437. https://doi.org/ 10.1080/13639080.2010.515967

Tomlinson, M., \& Holmes, L. (2017). Graduate employability context: Theory, research and debate. London: Palgrave-McMillan.

Yorke, M., \& Knight, P. (2007). Evidence-informed pedagogy and the enhancement of student employability. Teaching in Higher Education, 12(2), 157-170. https://doi. org/10.1080/13562510701191877 